\title{
Palaeoclimatic changes in the NW Iberian Peninsula during the last 3000 years inferred from diagenetic proxies in the Ría de Muros sedimentary record
}

\author{
A. Andrade, B. Rubio*, D. Rey, P. Álvarez-Iglesias, A. M. Bernabeu, F. Vilas \\ GEOMA, Marine and Environmental Geology Group, Department of Marine Geosciences, University of Vigo, \\ Campus As Lagoas-Marcosende, 36310 Vigo, Spain
}

\begin{abstract}
The Ría de Muros is the northernmost of the 4 Rías Baixas and, like the others, is subject to seasonal upwelling. The high organic carbon content of its sediments (average $2.4 \%$ ) is due to the consequent high primary production together with significant continental input from river discharge and runoff. This high organic carbon content not only favours early diagenesis, but does so to an extent that depends on the relative proportions of labile marine organic carbon and refractory terrestrial organic carbon. Thus, changes in early diagenesis reflected in the mineralogy and/or composition of the Ría's sediments can throw light on the degree of oceanic influence in the Ría, and hence on changes in the circulation and ventilation of its water masses and/or the climate on shore. In this study of sediment cores taken in the outer Ría de Muros, the combined use of textural analysis, magnetic properties (magnetic susceptibility [ $\mathrm{\kappa}$, ratio of anhysteretic to isothermal remanent magnetisation [ARM:IRM], and median destructive field [MDF]) and geochemical parameters (total concentrations of diagenetically stable and mobile elements in sediment and pore water) allowed the identification of a current redox front and 2 palaeosedimentary redox fronts in the sediment record. These fronts originated during periods of high marine/terrestrial organic matter ratio (as inferred from the ratio of total organic carbon to total nitrogen [TOC:TN] and $\delta^{13} \mathrm{C}$ ). Sedimentation rates calculated from ${ }^{14} \mathrm{C}$ dating results identify these periods as known periods of increased upwelling and reduced continental input due to colder, drier climate in the NW Iberian Peninsula, namely the Little Ice Age, the Dark Ages, and first cold period of the Upper Holocene.
\end{abstract}

KEY WORDS: Upwelling - Ría de Muros sediments · Organic matter origin · Diagenesis · Upper Holocene palaeoclimate

\section{INTRODUCTION}

Interest in climatic variations during the Holocene has grown markedly in recent years (e.g. Bond et al. 1997, Mayewski et al. 2004). The sediments of coastal areas such as the Galician Rías Baixas (NW Iberian Peninsula), where land and sea interdigitate, are a valuable source of information, since their high sedimentation rates of 0.2 to $10 \mathrm{~mm} \mathrm{yr}^{-1}$ (Rubio et al. 2001, Álvarez-Iglesias et al. 2007, Pena et al. 2007) facilitate studies of high resolution. In addition, since they are under the influence of both land and sea, they exhibit patterns of interaction between the two that can help discriminate among local, regional and global climate processes.

The Ría de Muros is the northernmost of the Rías Baixas, and is distinguished from the rest by being the only one that has no barrier islands at its mouth (see Fig. 1). This absence allows freer exchange of oceanic water masses and means greater exposure to sea swell, the energy of which totally controls the distribution of surface sediments, concentrating the finer fraction on the northern side of the Ría (Vilas et al. 2010). The average annual rainfall in the area is between 1443 and $1791 \mathrm{~mm}$, and the main source of freshwater input to the Ría is the River Tambre. The 2 main rock types of 
the drainage basin associated with the Ría are schists and two-mica granites (IGME 1978), both of which have secondary ferrimagnetic constituents (Cuesta \& Gallastegui 2004) that must be taken into account in interpreting the magnetic properties of the sediments of the Ría.

The Galician coast is one of the regions of the world with the most intense coastal upwelling (Wooster et al. 1976). Upwelling occurs mainly between April and October, and causes the entry into the Rías of cold, nutrient-rich East North Atlantic Central Water (ENACW) (Fraga 1981). The rest of the year, winds from the south favour the reverse pattern of movement, impeding the entry of ENACW and forcing the waters of the Rías to sink towards the continental shelf (Wooster et al. 1976, Fraga, 1981). To the north of the Ría, near Cape Finisterre, the subpolar ENACW component (ENACWsp) converges with the warmer, less oxygenated and more saline subtropical component (ENACWst) (Fraga 1991, Pérez et al. 1993), and the dependence of this front on meteorological and oceanographic factors (Álvarez-Salgado et al. 1993) makes the Ría de Muros an ideal site for palaeoceanographic studies.

The patterns of precipitation and aridity in this region are controlled by the North Atlantic Oscillation (NAO), the difference in sea-level atmospheric pressure between the Azores High and the Icelandic Low (Björck et al. 2006). Atmospheric storminess and increased precipitation on the Iberian Peninsula coincide with periods of negative NAO, and dry periods with positive NAO (Hurrell 1995). This parameter varies on decadal timescales, but shows extended phases of both positive and negative periods.

As a result of the seasonal upwelling and continental contributions, the organic matter contents of Rías Baixas sediments are very high (Vilas et al. 2005), and this favours intense diagenetic processes (Rubio et al. 2001, 2010, Emiroglu et al. 2004, Rey et al. 2005, Álvarez-Iglesias \& Rubio 2008). Thus, the final chemical and mineralogical composition of the sediments depends on (1) continental input (river and surface water runoff), which in turn depends mainly on rainfall and supplies organic material and detritus of terrestrial origin; (2) primary production of biomass, which depends mainly on the seasonal upwelling and provides not only labile organic matter but also biogenic inorganic material (calcium carbonate, opal, etc.); and (3) early diagenesis, which is governed mainly by the amount and reactivity of organic matter and the degree of oxygenation of the sediment.

Recent studies of the Rías Baixas and the adjacent continental shelf have confirmed the value of this area as a record of the climatic changes that occurred during the Holocene (Diz et al. 2002, Desprat et al. 2003,
Álvarez et al. 2005, González-Álvarez et al. 2005, Martins et al. 2006, 2007, Pérez-Arlucea et al. 2007, Bernárdez et al. 2008a,b, Mohamed et al. 2010). However, the only palaeoclimatic studies of the Ría de Muros concern 2 cores collected in the outer and middle areas of the Ría (EUGC-2 and EUGC-3B; Lebreiro et al. 2006, Pena et al. 2007, 2010). Those studies detected an increase in coastal upwelling that in the outer Ría began approximately 800 yr before present (calibrated, cal. yr BP) and which began to affect the inner Ría about $200 \mathrm{cal}$. yr BP; and on a longer time scale the outer core shows 6 positive excursions of benthic foraminiferal $\delta^{13} \mathrm{C}$ during the last $8200 \mathrm{cal}$. yr BP (Pena et al. 2007). Pena et al. (2010) interpreted these excursions as reflecting an increase in the exportation of organic matter to the continental shelf associated with an intensification of ENACWsp upwelling and a decrease in fluvial input, and found correlation between these events and the century/millenniumscale climatic disturbances that took place at low latitudes in the North Atlantic during the Holocene, the 1500 yr cycles in particular (Bond et al. 1997). However, in this type of environment, in which sediment dynamics governs changes in the distribution and composition of sediment, it is essential to consider multiple proxies.

In the present multi-proxy study, geochemical, magnetic and texture data were used to identify changes in the intensity of early diagenetic processes that were triggered by changes in the ratio of oceanic (labile) and terrestrial (refractory) organic matter inputs. From this sequence of events, we inferred the palaeoclimatic evolution of the Ría de Muros during the past 3000 yr. This is one of the first palaeoclimatic studies of NW Iberia based on the relationship between the intensity of diagenetic processes and the provenance of sedimentary organic matter.

\section{MATERIALS AND METHODS}

A $2.5 \mathrm{~m}$ gravity core (M5GC) and an $18 \mathrm{~cm}$ box core (M5BC) were collected on the RV 'Mytilus' in the outer area of the Ría de Muros at $42^{\circ} 44^{\prime} \mathrm{N}, 9^{\circ} 02^{\prime} \mathrm{W}$ (Fig. 1).

\subsection{M5GC}

M5GC was extracted in June 2004 and was kept at a temperature of 1 to $4^{\circ} \mathrm{C}$ until opened. At the time of its opening, the colour of the sediment was determined using a Konica Minolta CM-2600d spectrophotometer, the core was divided into segments $3 \mathrm{~cm}$ long, and samples of the centres of the segments were removed with U-channels. 


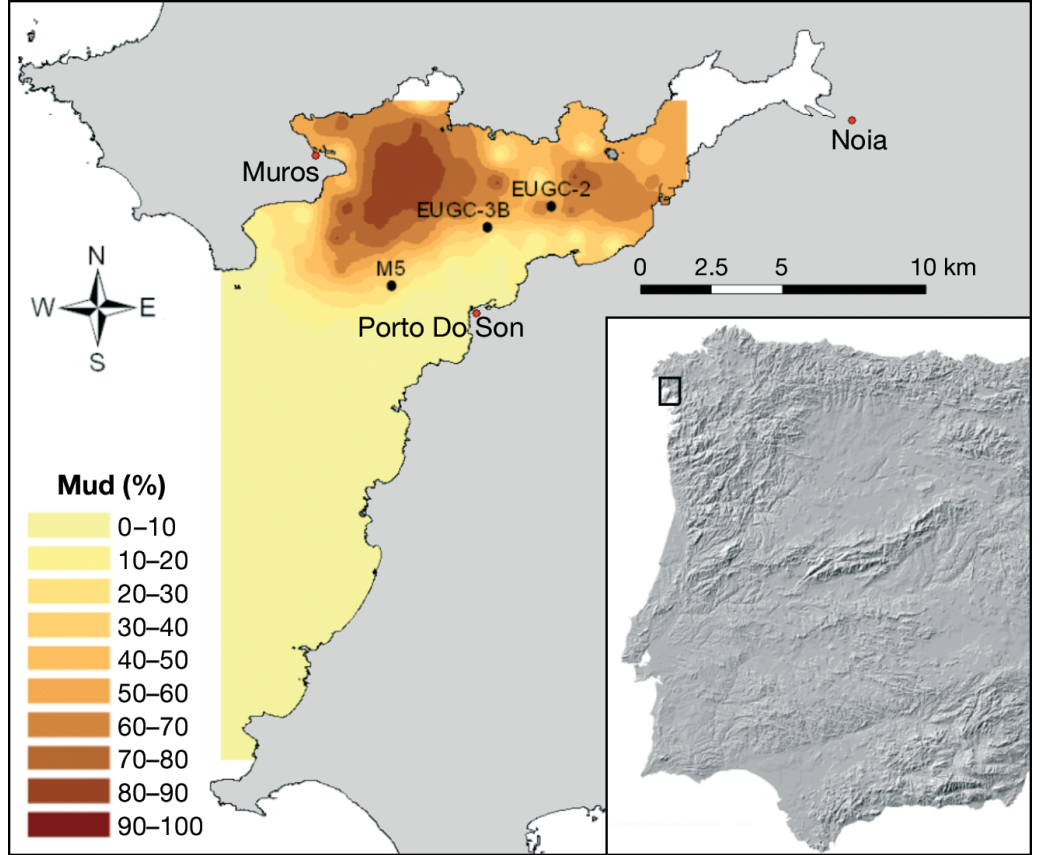

Fig. 1. Positions of the cores M5 (M5BC and M5GC), EUGC-2 and EUGC-3B (Lebreiro et al. 2006, Pena et al. 2007, 2010) on a map of surficial mud distribution in the Ría de Muros

X-ray fluorescence measurements of the U-channel samples were performed at the University of Vigo with an ITRAX Core Scanner. Semiquantitative analysis (cps, counts per second) was performed for 22 elements with a resolution of $300 \mu \mathrm{m}$ using a $\mathrm{Cr}$ anode and a dwell time of $10 \mathrm{~s}$.

Magnetic parameters were measured (with $1 \mathrm{~cm}$ resolution unless otherwise stated) at the Marine Geophysical Laboratory of the University of Bremen. Magnetic susceptibility ( $\kappa)$ was measured at $580 \mathrm{~Hz}$ with an automatic meter with a Bartington MS2F sensor. Isothermal remanent magnetisation (IRM), anhysteretic remanent magnetisation (ARM) and alternating field (AF) demagnetisation curves were constructed with a 2G Enterprises 755R triaxial DC SQUID magnetometer. For ARM, AFs of $100 \mathrm{mT}$ and a direct current (DC) of $50 \mu \mathrm{T}$ were used. For IRM, magnetic field intensity was progressively increased to $700 \mathrm{mT}$, at which point saturation IRM (SIRM) was deemed to have been reached. AF demagnetisation curves, obtained using fields of increasing intensity up to $100 \mathrm{mT}$, were used to calculate the median destructive field (MDF), which achieves $50 \%$ demagnetisation of SIRM. The response to cooling of a sample of approximately $10 \mathrm{mg}$ taken at a depth of $5 \mathrm{~cm}$ was recorded with a magnetic property measurement system (MPMS XL7); curves were constructed both under zero field (ZFC) and in the presence of a magnetic field of $5 \mathrm{~T}$ (FC).

Samples taken at $3 \mathrm{~cm}$ intervals were dried in an oven at a temperature below $60^{\circ} \mathrm{C}$, ground in an agate ball mill and analysed in a LECO CN 2000 elemental analyser for total contents of organic carbon (TOC; $\sigma=0.001$, RSD [relative standard deviation] $=0.4 \%$ ) and nitrogen ( $\mathrm{TN} ; \sigma=0.01, \mathrm{RSD}=0.3 \%$ ), in a LECO CC100 for total inorganic carbon $\left(\mathrm{TIC}_{i} \sigma=0.001, \mathrm{RSD}=0.3 \%\right.$ ), in a Carlo Erba EA 1108 for total sulphur (TS; $\sigma=0.002, \mathrm{RSD}<0.2 \%$ ), and in a Siemens SRS 3000 X-ray fluorescence (XRF) spectrometer for major and trace elements. Additionally, for semiquantitative mineralogical analysis, these samples were subjected to X-ray diffractometry (XRD) in a Siemens D-5000 apparatus using $\mathrm{Cu}-\mathrm{K} \alpha$ radiation.

Samples taken every $6 \mathrm{~cm}$ from the upper $30 \mathrm{~cm}$ of the core and every $12 \mathrm{~cm}$ from the remaining $220 \mathrm{~cm}$ were used for measurements of the $\delta^{13} \mathrm{C}$ value (the proportional deviation of the ${ }^{13} \mathrm{C}:{ }^{12} \mathrm{C}$ ratio from the Vienna Pee Dee Belemnite standard, in parts per thousand) of their organic matter, the ratio of refractory to total organic matter $(R p ;$ Kristensen 1990), and grain size distribution. For the $\delta^{13} \mathrm{C}$ value of organic matter, carbonates were first removed with $\mathrm{HCl}$. The sample was then washed with Milli-Q water and dried, and about $0.1 \mathrm{mg}$ was placed in an Sn capsule for combustion and subsequent analysis in a Thermo-Finnigan MAT253 mass spectrometer. $R p$ was calculated assuming that labile organic matter is lost by combustion at $250^{\circ} \mathrm{C}$ and total organic matter by combustion at $500^{\circ} \mathrm{C}$ (Loh et al. 2008), an assumption justified by the high organic matter content of these sediments. Grain size distributions were determined by wet and dry sieving (Folk, 1974), and by X-ray nephelometry in a Micromeritics SediGraph 5100 for the fraction smaller than $63 \mu \mathrm{m}$.

Electron micrographs and certain compositional data were obtained from selected samples using a JEOL JSM6700F field emission scanning electron microscope (FESEM) coupled to a backscattered electron detector.

At the ITN Radiocarbon Laboratory (Sacavém, Portugal), ${ }^{14} \mathrm{C}$ dating was performed by liquid scintillation counting (LSC) on a whole shell of Dosinia exoleta that was collected in life position at $90 \mathrm{~cm}$ and showed no visual signs of surface deterioration. A second dating sample, consisting of approximately $10 \mathrm{mg}$ of foraminiferal species, was manually extracted from a sediment sample taken at $54 \mathrm{~cm}$ and was dated using the AMS ${ }^{14} \mathrm{C}$ facilities of the LABEC laboratory at INFN-Firenze (Italy). Calibrated ages were calculated with the program CALIB 6.0 (Stuiver \& Reimer 1993) using the marine ${ }^{14} \mathrm{C}$ calibration curve (Reimer et al. 2009). No local reservoir 
correction was used for the sample collected at $54 \mathrm{~cm}$ because the limited data available for the periods to be dated shows minimal lag between the atmospheric ${ }^{14} \mathrm{C}$ content and surface water (Soares \& Dias 2006, 2007). However, for the sample collected at $90 \mathrm{~cm}$, a local reservoir value of $220 \pm 28$ yr was applied as per Soares $\&$ Dias (2007). Calibrated ages are reported $\pm 2 \sigma$.

\subsection{M5BC}

From M5BC, extracted in June 2009, 2 parallel cores were obtained in PVC pipes, in one of which holes had previously been drilled every $3 \mathrm{~cm}$ for insertion of Rhizon core solution samplers. In the pore water samples so obtained, the total concentrations of dissolved Fe were determined by electrothermal atomic absorption spectrometry (ETAAS), Mn and V by inductively coupled plasma optical emission spectrometry (ICP-OES), and $\mathrm{Cu}, \mathrm{Ni}, \mathrm{Pb}$ and $\mathrm{Zn}$ by inductively coupled plasma mass spectrometry (ICP-MS). The other pipe was opened for elemental analysis by XRF spectrometry in the ITRAX core scanner at the University of Vigo, using the same conditions as for M5GC.

All elemental analyses and $\delta^{13} \mathrm{C}$ values of samples of sediment or pore water were performed at CACTI, the scientific and technological research support facility of the University of Vigo.

\section{RESULTS}

\subsection{Relationship between M5GC and M5BC}

By means of the high-resolution XRF spectrometry results for $\mathrm{Al}, \mathrm{Ti}, \mathrm{Fe}$ and $\mathrm{Mn}$ concentrations, the 2 cores were matched with an accuracy of about $1 \mathrm{~mm}$ (Fig. 2), sufficient for direct comparison of the results of conventional XRF analyses performed every $3 \mathrm{~cm}$, and for confirmation of the integrity of the top of the gravity core. No significant differences were found between the M5BC data and those of the top $18 \mathrm{~cm}$ of M5GC, and in what follows all results refer to M5GC except those for pore water.

\subsection{Geochronology}

The sedimentation rates inferred from the $2{ }^{14} \mathrm{C}$ datings of marine carbonates are very similar (Table 1). Extrapolation to the whole core yields an approximate date of 8000 cal. yr BP for its bottom.
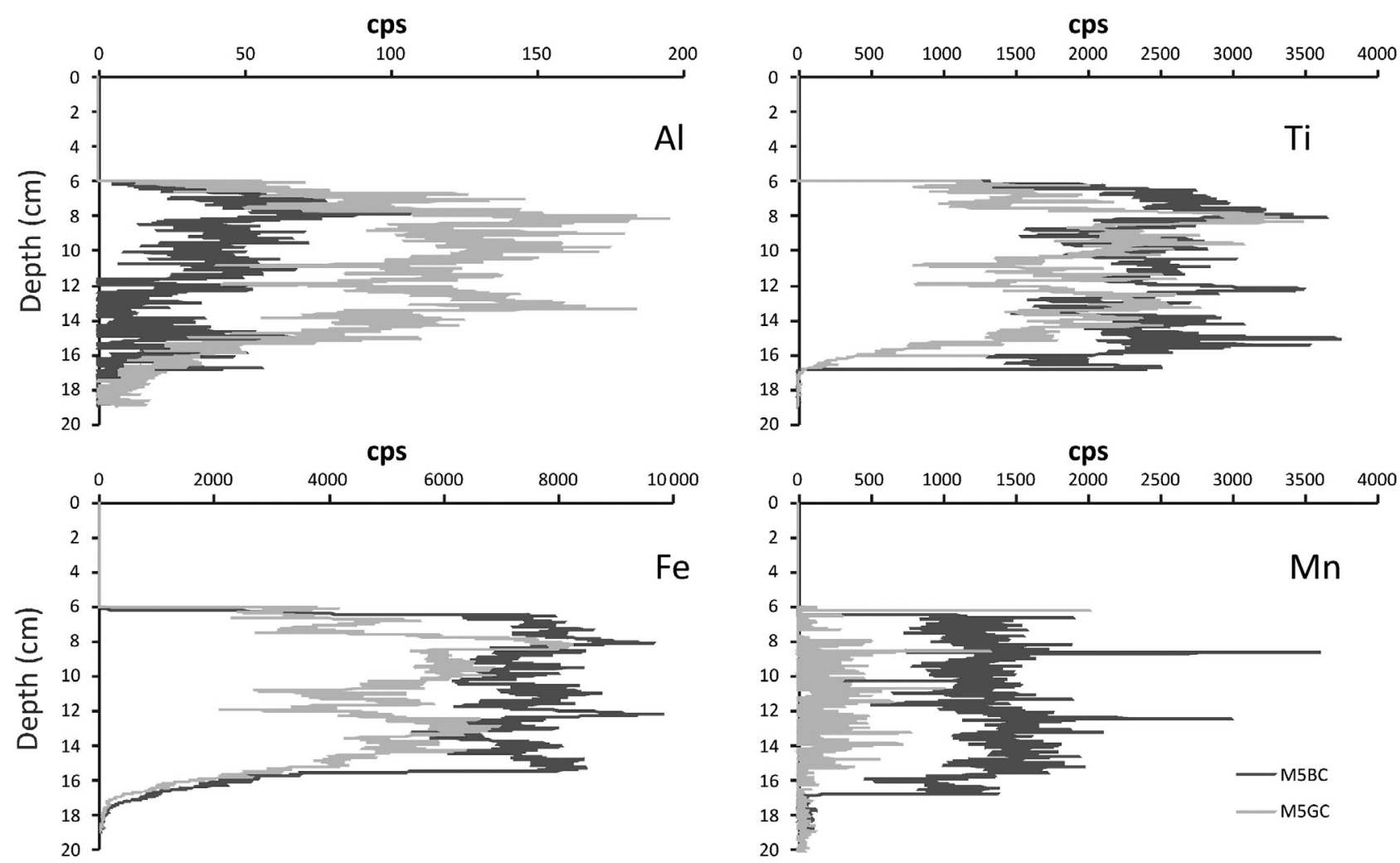

Fig. 2. Matching of high-resolution X-ray fluorescence data for Al, Ti, Fe and Mn in sediment cores M5BC and M5GC; cps: counts per second 


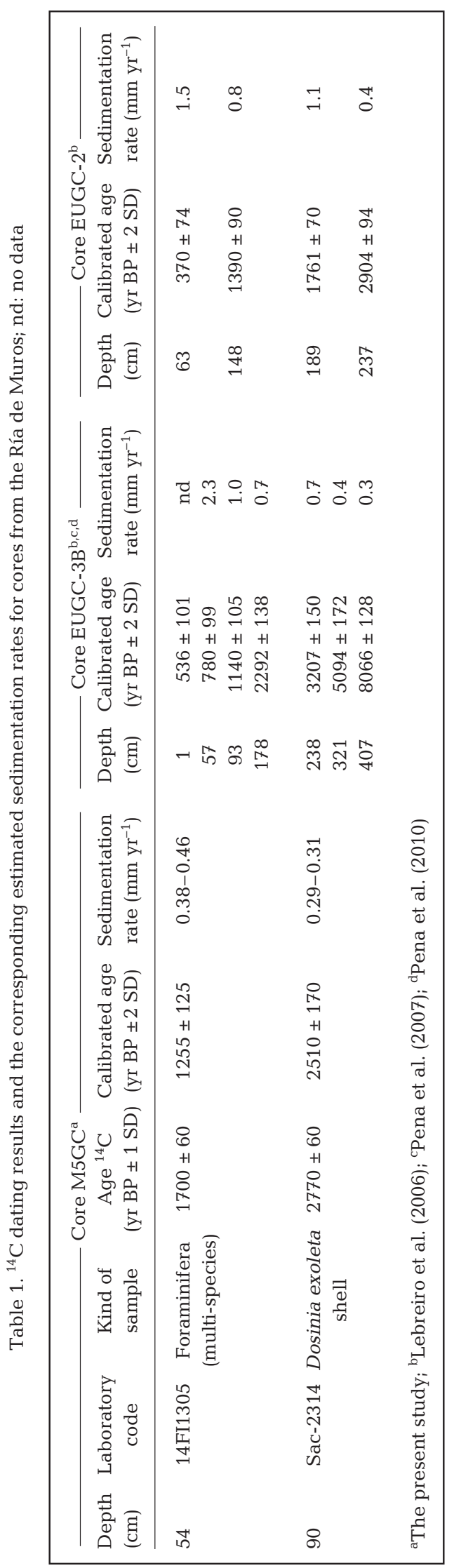

\subsection{Lithological characteristics}

Initial visual assessment of the gravity core upon opening identified an abundance of gravel and bioclastic sand throughout its length. The core was dark grey (Munsell ${ }^{\circledR}$ colour code 6Y 3/1), except for the top $15 \mathrm{~cm}$, where it was more brownish (Munsell 4Y 3/1).

Texture analysis showed the sand fraction to predominate throughout the core, with an average sand content of $47 \%$ (Fig. 3). The textural group was slightly gravelly muddy sand in the top $12 \mathrm{~cm}$ and from 150 to $250 \mathrm{~cm}$, and gravelly muddy sand from 18 to $138 \mathrm{~cm}$ (Fig. 3).

XRD showed the dominant minerals to be calcite, aragonite and quartz, which together constituted around $60 \%$ of the mineral content of the sample (Fig. 3). The other minerals detected by XRD were phyllosilicates (8 to $13 \%$ ) and feldspars (4 to $13 \%$ ) derived by weathering from the typical rocks of the drainage basin of the Ría de Muros (IGME 1978).

\subsection{Geochemical composition of the solid phase}

The average concentrations of major and minor elements are listed in Table 2, and the corresponding concentration profiles are shown in Fig. 3.

The profiles of the diagenetically stable elements $\mathrm{Al}$ and $\mathrm{Ti}$, which are commonly used as proxies of terrigenous input (Thompson et al. 1998), are very similar. Their concentrations are fairly uniform in the first $6 \mathrm{~cm}$, increase by $25 \%$ at a depth of $9 \mathrm{~cm}$, and then decrease progressively down to $30 \mathrm{~cm}$ except for a small peak around $27 \mathrm{~cm}$. Below $30 \mathrm{~cm}$ there is very little variation except for a small sharp peak around $72 \mathrm{~cm}$; the concentration below $30 \mathrm{~cm}$ is everywhere significantly lower than in the top $27 \mathrm{~cm}$. The noticeable increase in the observed concentration between the top and $27 \mathrm{~cm}$ appears to be related to the increased fine-sediment content in this section.

Although $\mathrm{Fe}, \mathrm{Mn}$ and $\mathrm{V}$ are commonly subject to diagenesis, their concentration profiles are nevertheless similar to those of $\mathrm{Al}$ and $\mathrm{Ti}$ (the main difference consisting in sharp peaks in Mn at depths of 120 and $240 \mathrm{~cm}$ ). This similarity implies that a significant part of their variability is attributable to changes in detrital input. Normalisation of the profiles relative to Al highlights the 3 peaks at 27, 72 and $120 \mathrm{~cm}$ (Fig. 4 shows the normalised profiles of $\mathrm{Fe}$ and $\mathrm{Mn}$ ).

The profiles of As and P differ somewhat from those of the other diagenetically mobile elements. That of As is similar to those of $\mathrm{Fe}, \mathrm{Mn}$ and $\mathrm{V}$ down to $18 \mathrm{~cm}$, where it begins to rise to the $27 \mathrm{~cm}$ peak; but below this peak As concentrations are below the detection limit $\left(10 \mu \mathrm{g} \mathrm{g}^{-1}\right)$ except around 69-72, 96, 186 and $225-240 \mathrm{~cm}$, at which levels there is an average con- 

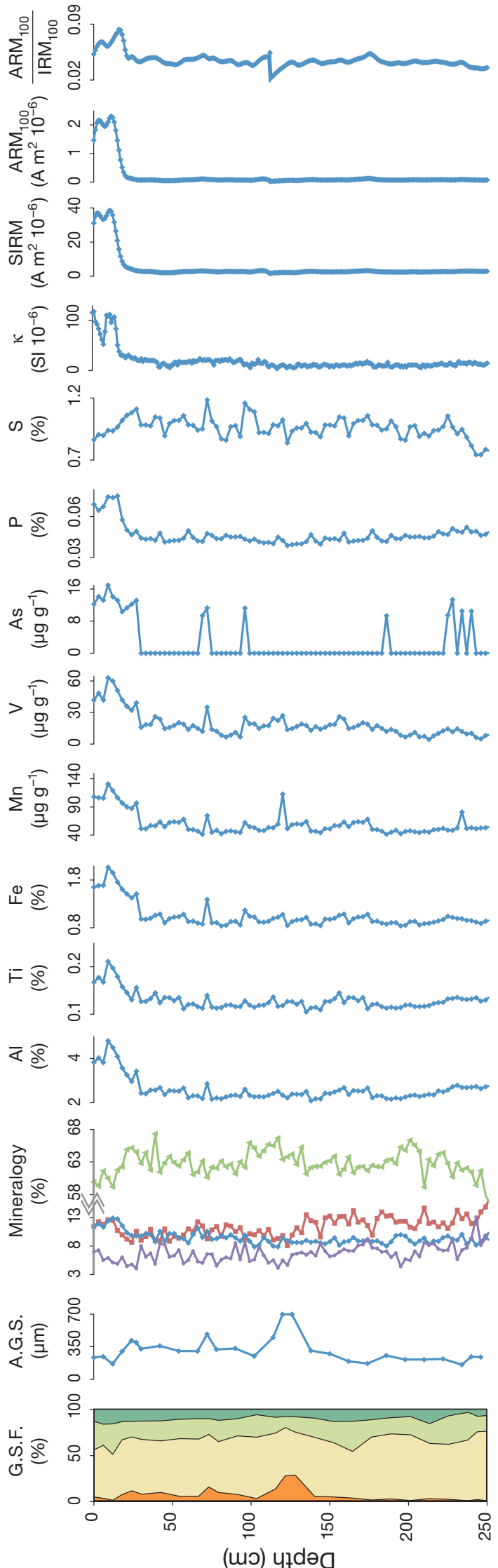

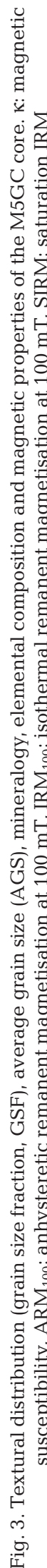

Table 2. Mean values $( \pm \mathrm{SD})$ of element concentrations, $\delta^{13} \mathrm{C}$ and magnetic properties in core M5GC. TOC: total organic carbon, TN: total nitrogen; TS: total sulphur, $\kappa:$ magnetic susceptibility, $\mathrm{ARM}_{100}$ : anhysteretic remanent magnetisation at $100 \mathrm{mT}, \mathrm{IRM}_{100}$ : isothermal remanent magnetisation, SIRM: saturation IRM, MDF: median destructive field

\begin{tabular}{|c|c|}
\hline Parameter & Value \\
\hline $\mathrm{Al}(\%)$ & $2.59 \pm 0.518$ \\
\hline $\operatorname{Ti}(\%)$ & $0.129 \pm 0.0185$ \\
\hline $\mathrm{Fe}(\%)$ & $1.04 \pm 0.255$ \\
\hline $\operatorname{Mn}\left(\mu g g^{-1}\right)$ & $59.8 \pm 19.5$ \\
\hline $\mathrm{V}\left(\mu \mathrm{g} \mathrm{g}^{-1}\right)$ & $18.3 \pm 11.8$ \\
\hline As $\left(\mu g g^{-1}\right)$ & $2.63 \pm 5.06$ \\
\hline $\mathrm{P}(\%)$ & $0.047 \pm 0.0075$ \\
\hline TOC (\%) & $2.40 \pm 0.660$ \\
\hline TN (\%) & $0.21 \pm 0.065$ \\
\hline TS (\%) & $0.96 \pm 0.084$ \\
\hline$\delta^{13} \mathrm{C}(\%)$ & $-22.5 \pm 0.45$ \\
\hline$\kappa\left(\times 10^{-6} \mathrm{SI}\right)$ & $18.8 \pm 20.6$ \\
\hline $\mathrm{ARM}_{100}\left(\mathrm{~A} \mathrm{~m}^{2}\right)$ & $2.01 \times 10^{-7} \pm 4.69 \times 10^{-7}$ \\
\hline $\operatorname{SIRM}\left(\mathrm{A} \mathrm{m}^{2}\right)$ & $4.70 \times 10^{-6} \pm 7.61 \times 10^{-6}$ \\
\hline $\mathrm{MDF}(\mathrm{mT})$ & $39.6 \pm 6.76$ \\
\hline ARM:IRM & $0.0441 \pm 0.0090$ \\
\hline
\end{tabular}

centration of $1.4 \mathrm{\mu g} \mathrm{g}^{-1}$. Note that the peak at $96 \mathrm{~cm}$ is echoed by insignificant but recognisable rises in $\mathrm{Al}, \mathrm{Ti}, \mathrm{Fe}, \mathrm{Mn}$ and $\mathrm{V}$. The $\mathrm{P}$ profile is singular in that it reaches its first peak at a greater depth than the others $(15 \mathrm{~cm})$ and falls to the sub-30 cm plateau with only the slightest hint of a peak at $27 \mathrm{~cm}$. Below $30 \mathrm{~cm}, \mathrm{P}$ concentration is very stable at a value around $60 \%$ less than in the top $15 \mathrm{~cm}$, and the very small peaks it does show are in general unrelated to peaks in the other element profiles.

The $\mathrm{S}$ concentration profile in the core is completely different from those of $\mathrm{Al}, \mathrm{Ti}, \mathrm{Fe}, \mathrm{Mn}, \mathrm{V}$ and $\mathrm{P}$. It presents an increasing trend from the top to $30 \mathrm{~cm}$. From there to the bottom, the values remain approximately constant, with the exception of specific increases at 72, 96, 120 and $225 \mathrm{~cm}$. S may be present in sediments in an organic or inorganic form. To distinguish between both sources, we have calculated the ratio S:TOC (Berner \& Raiswell 1983, our Fig. 4). Maxima occur located at 27,72 and $120 \mathrm{~cm}$, coinciding with $\mathrm{Fe}: \mathrm{Al}$ and $\mathrm{Mn}: \mathrm{Al}$ mentioned above.

\subsection{Organic matter}

In the core as a whole, TOC is $2.40 \pm 0.66 \%$. Its profile (Fig. 4) shows the same grain-size related peak as the metals around $9 \mathrm{~cm}$; more generally, TOC is significantly correlated with the percentage of particles smaller than $63 \mu \mathrm{m}\left(\mathrm{r}^{2}=0.4\right.$, $\left.\mathrm{p}<0.001\right)$. Below $21 \mathrm{~cm}$, TOC content tends to fall progressively, with short rises between 21 and $27 \mathrm{~cm}$, be- 


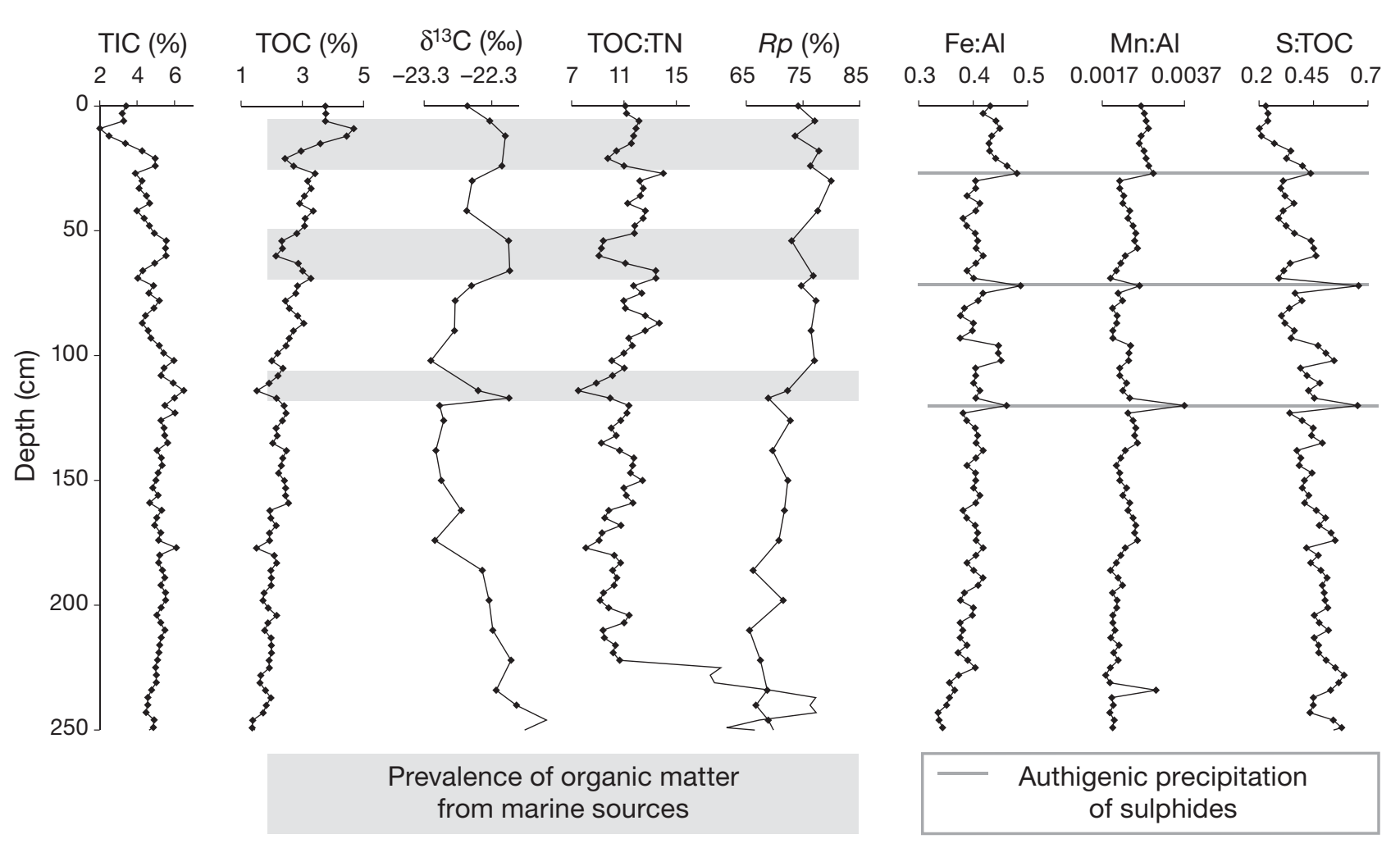

Fig. 4. Total inorganic carbon (TIC), total organic carbon (TOC), $\delta^{13} \mathrm{C}$, the ratio of TOC to total nitrogen (TN), the ratio of refractory to total organic matter $(R p)$, and the $\mathrm{Fe}: \mathrm{Al}, \mathrm{Mn}: \mathrm{Al}$ and $\mathrm{S}$ :TOC ratios in core M5GC. The 3 periods of increased marine influence are indicated by shading, and the location of increased precipitation of authigenic sulphides by horizontal lines

tween 60 and $69 \mathrm{~cm}$, and between 114 and $120 \mathrm{~cm}$ being outweighed by diminution between 27 and $60 \mathrm{~cm}$, 69 and $114 \mathrm{~cm}$, and 120 and $250 \mathrm{~cm}$. TIC content ranges from 2.0 to $6.5 \%$, with an average of $4.9 \%$, and exhibits a profile that is almost antisymmetric to that of TOC $\left(\mathrm{r}^{2}=0.7, \mathrm{p}<0.001\right)$.

The origin of organic matter was elucidated using $\delta^{13} \mathrm{C}$, which ranges from -21.5 to $-23.2 \%$, and the TOC:TN ratio, which ranges from 7.5 to 13.5 (Fig. 4). The profiles of these parameters have 3 sections (6-24, 54-66 and $111-117 \mathrm{~cm}$ ) in which the TOC:TN ratio is lower and $\delta^{13} \mathrm{C}$ less negative than elsewhere; $t$-tests show the mean values of the TOC:TN ratio and $\delta^{13} \mathrm{C}$ in these 3 sections to differ significantly $(p \leq 0.05)$ from those of the rest of the core.

The parameter $R p$, an indicator of the degradability of organic matter (Loh et al. 2008), shows a general decreasing trend from the top to the base of the core $\left(\mathrm{r}^{2}=0.67\right)$, though with deviations from this trend in the 0-30, 54-66 and 111-117 cm sections (Fig. 4).

\subsection{Geochemical composition of pore waters}

The concentrations of $\mathrm{Fe}$ and $\mathrm{Mn}$ in pore waters increase from 3 to $15 \mathrm{~cm}$ (Fig. 5). V concentration peaked at $12 \mathrm{~cm}$, fell sharply, and below $15 \mathrm{~cm}$ was less than the detection limit $\left(5 \mu \mathrm{g} \mathrm{l}^{-1}\right)$. Note that for all 3 metals, concentration peaked a little below the first peak in the sediment.

\subsection{Magnetic properties}

Average values of magnetic parameters are listed in Table 2. The profiles of properties related to the concentration of magnetic minerals ( $\kappa$, ARM, SIRM) are quite similar (Fig. 3), with much higher values in the top $18 \mathrm{~cm}\left(\kappa=30.8 \times 10^{-6}\right.$ to $117.7 \times 10^{-6} \mathrm{SI}$; ARM $=5.13$ $\times 10^{-7}$ to $2.30 \times 10^{-6} \mathrm{~A} \mathrm{~m}^{2}$; $\mathrm{SIRM}=8.76 \times 10^{-6}$ to $3.86 \times$ $\left.10^{-5} \mathrm{~A} \mathrm{~m}^{2}\right)$ than in the rest of the core $\left(\kappa=3.6 \times 10^{-6}\right.$ to $30.8 \times 10^{-6} \mathrm{SI} ; \mathrm{ARM}=2.04 \times 10^{-8}$ to $3.42 \times 10^{-7} \mathrm{~A} \mathrm{~m}^{2}$; $\mathrm{SIRM}=1.29 \times 10^{-6}$ to $6.93 \times 10^{-6} \mathrm{~A} \mathrm{~m}^{2}$ ). The maximum values of ARM and SIRM are found between 10 and $11 \mathrm{~cm}$, and those of $\kappa$ at $0-1$ and $11 \mathrm{~cm}$ (Fig. 5). The ARM:IRM ratio is also greater in the top $18 \mathrm{~cm}$ than below this level (Fig. 3), with its maximum value at $16 \mathrm{~cm}$. Below $18 \mathrm{~cm}$, the ARM and SIRM profiles are practically flat, and those of $\kappa$ and the ARM:IRM ratio also show much less variation than above this level.

The MDF, a parameter related to the magnetic coercivity of the sample, has a profile that practically mir- 

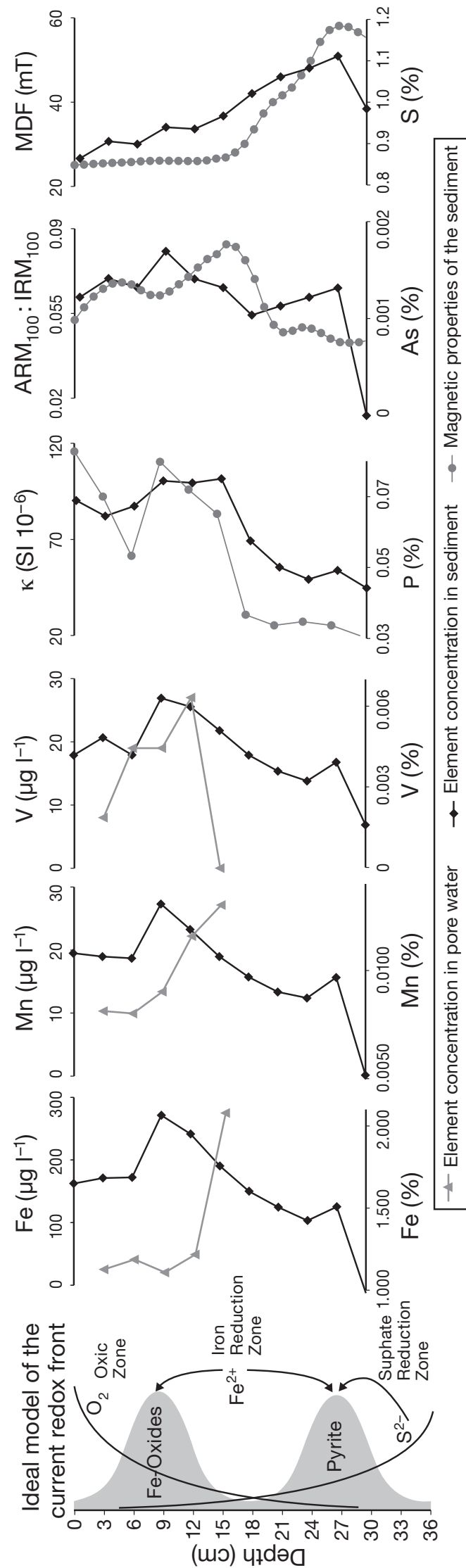

rors that of the ARM:IRM ratio. The lowest values were found between the top of the core and $15 \mathrm{~cm}$. Between 15 and $27 \mathrm{~cm}$, it increases to its maximum (Fig. 5), and from there it decreases until $69 \mathrm{~cm}$ (Fig. 3). From this depth the MDF increases (69-90, 108-117, 171$186 \mathrm{~cm})$ and decreases $(90-108,117-171 \mathrm{~cm})$ with little variation from $186 \mathrm{~cm}$ to the base of the core.

\subsection{Detection of micro- and nanominerals in selected samples}

Micrographs of the levels exhibiting enrichment with the diagenetically mobile elements Fe, Mn, V or $\mathrm{S}(27,72$ and $120 \mathrm{~cm})$ reveal an abundance of minerals with framboidal structure (Fig. 6) that were shown to be pyrite by the Fe:S ratio of 1:2 determined by XRF microanalysis. At $27 \mathrm{~cm}$, the presence of arsenopyrite was detected (Fig. 6a). In samples taken at 6 and $60 \mathrm{~cm}$, the presence of pyrite was limited to microenvironments such as the interior of foraminifer shells or interlayers of mineral structures (Fig. 6b). Magnetite was not detected in any of the samples analysed by FESEM, but its presence at $5 \mathrm{~cm}$ is shown by the Verwey transition at $120 \mathrm{~K}$ in the ZFC and FC curves constructed from a sample taken at this depth (Fig. 7).

\section{DISCUSSION}

\subsection{Location of current and palaeosedimentary redox fronts}

The change in colour of the core at $15 \mathrm{~cm}$ may be attributed partly to the higher mud content of the top $15 \mathrm{~cm}$, and partly to diagenetic causes.

The mineralisation of sedimentary organic matter by microorganisms requires the presence of terminal electron acceptors: in decreasing order of energy produced, $\mathrm{O}_{2}, \mathrm{NO}_{3}^{-}, \mathrm{Mn}$ oxides (or $\mathrm{Mn}^{\mathrm{IV}}$ ), Fe oxides (or $\mathrm{Fe}^{\mathrm{III}}$ ), and sulphate $\left(\mathrm{SO}_{4}{ }^{2-}\right)$ (Froelich et al. 1979). Unlike the acceptors preceding them in this sequence, Fe and Mn (oxyhydr)oxides are found in the solid phase. Their reduction, largely by bacteria that degrade organic matter, therefore involves an increase in the concentration of these elements in pore waters, and the diffusion of the reduced species in solution into upper regions of the sediment column is followed by their oxidation by dissolved oxygen and subsequent precipitation in the form of (oxyhydr)oxides (Froelich et al. 1979). This is what seems to be occurring in M5GC, where the Fe and $\mathrm{Mn}$ concentrations in pore water increase between 12 and $15 \mathrm{~cm}$ (Fig. 5), while the $\mathrm{Fe}: \mathrm{Al}$ and $\mathrm{Mn}: \mathrm{Al}$ ratios peak around $9 \mathrm{~cm}$ (Fig. 4). 

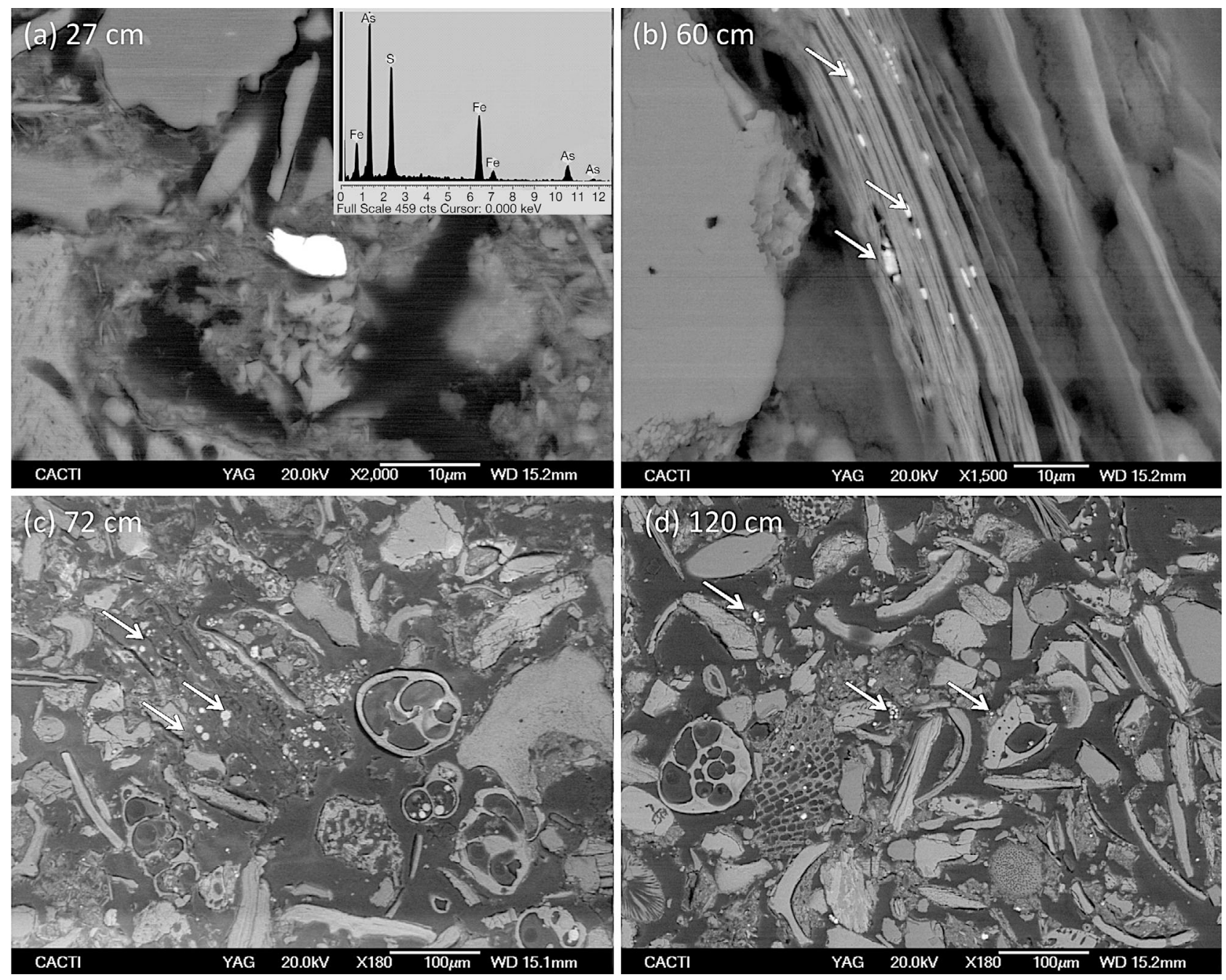

Fig. 6. Scanning electron micrographs in backscattered electron mode of samples from core M5GC. (a) Co-precipitation of As with Fe sulphides at $27 \mathrm{~cm}$ (inset: the X-ray fluorescence spectrum obtained for elemental analysis). (b) Precipitation of pyrite limited to microenvironments at $60 \mathrm{~cm}$. (c,d) Extensive precipitation of pyrite at depths of 72 and $120 \mathrm{~cm}$, respectively. Some of the pyrite particles are identified by arrows

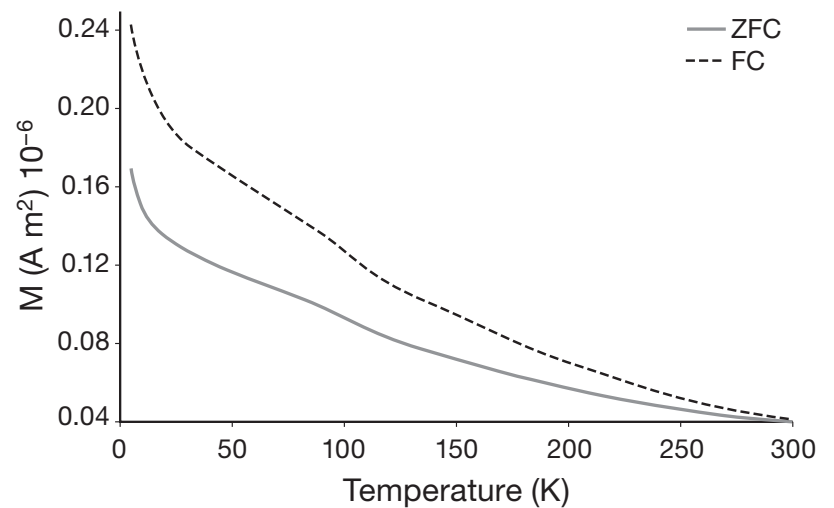

Fig. 7. Curves constructed in the presence of a magnetic field of $5 \mathrm{~T}$ (field cooling, FC) and zero field (zero field cooling, ZFC) for a sample taken at $5 \mathrm{~cm}$ depth. Note the Verwey transition at $120 \mathrm{~K}$
The diffusion of reduced species also occurs in deeper sediment, where after reacting with $\mathrm{S}^{2-}$ ions produced by sulphate reduction, $\mathrm{Fe}^{2+}$ ions precipitate in the form of authigenic sulphides (Froelich et al. 1979). To this reaction may be attributed the abundant presence of pyrites, and the resulting high $\mathrm{Fe}: \mathrm{Al}$ ratio and $\mathrm{S}$ content, at $27 \mathrm{~cm}$.

$\mathrm{P}$, As and $\mathrm{V}$ are not involved directly in biotic redox reactions, but they do take part in abiotic processes associated with the transition from the oxic zone, where the predominant electron acceptor is $\mathrm{O}_{2}$, to the suboxic zone, where $\mathrm{NO}_{3}^{-}, \mathrm{Mn}^{\mathrm{IV}}$ and $\mathrm{Fe}^{\mathrm{III}}$ are reduced (Froelich et al. 1979). Phosphates have a marked tendency to associate with Fe (oxyhydr)oxides and pass into dissolution when reduced (Shaw et al. 1990). This may explain the sharp decline in sediment $\mathrm{P}$ concentra- 
tion below $15 \mathrm{~cm}$, since this decline coincides with the increase in $\mathrm{Fe}$ in pore water.

That the sediment As profile has maxima at both 9 and $27 \mathrm{~cm}$ is attributable to arsenates associating both with Fe (oxyhydr)oxides and Fe sulphides (Mucci et al. 2000, Álvarez-Iglesias \& Rubio 2008). The former association occurs at $9 \mathrm{~cm}$, and the latter at $27 \mathrm{~cm}$, where arsenopyrites are seen in FESEM micrographs.

The reduction of $\mathrm{V}^{\mathrm{V}}$ to $\mathrm{V}^{\mathrm{IV}}$ in sediments is mainly determined by oxygen concentration. In suboxic conditions, $\mathrm{V}^{\mathrm{IV}}$ prevails in the form of the cation $\mathrm{VO}^{2+}$ (Wehrli \& Stumm 1989), and the great affinity of $\mathrm{VO}^{2+}$ for particle surfaces removes $\mathrm{V}$ from pore water. That this is what is occurring at a depth of around $15 \mathrm{~cm}$ in M5GC is supported by both the fall in $\mathrm{V}$ in pore water at this depth (Fig. 5) and by the evidence of the reduction of $\mathrm{Fe}$ (oxyhydr)oxides and $\mathrm{Mn}$ that has been discussed.

The dissolution of $\mathrm{Fe}$ oxides at around $15 \mathrm{~cm}$ is consistent with the results on magnetic properties (Fig. 5). In the top $15 \mathrm{~cm}$, low MDF values indicate the presence of titanomagnetite, a characteristic feature of this type of environment (Emiroglu et al. 2004, Rey et al. 2005, Mohamed et al. 2011), while high susceptibility values reflect the concentration of magnetite, which dominates the magnetic signal when present. The fall in magnetite content shown by the sharp fall in $\kappa$ between 15 and $18 \mathrm{~cm}$ is associated with an ARM:IRM peak at $16 \mathrm{~cm}$ indicative of a decrease in magnetite particle size (Banerjee et al. 1981) that suggests incipient dissolution. Below $16 \mathrm{~cm}$, the increase in MDF down to $27 \mathrm{~cm}$ reveals a change in magnetic mineralogy that the associated fall in the ARM:IRM ratio shows to involve the progressive dissolution of smaller magnetite grains (Snowball 1993).

The finding that TOC concentration falls by almost $50 \%$ in the zone in which Fe oxides are reduced (15 to $27 \mathrm{~cm}$ ) emphasises the significant role of Fe in the mineralisation of organic matter in these sediments. Similar processes have been described in other Galician Rías (León et al. 2004, Álvarez-Iglesias \& Rubio 2008, 2009) and in similar coastal environments with high concentrations of $\mathrm{Fe}$ and $\mathrm{Mn}$ and high input of labile organic matter (Sørensen \& Jørgensen 1987, Hines et al. 1991, Canfield et al. 1993, Haese et al. 2000). Fig. 5 shows a schematic representation of the current diagenetic zonation in the upper core, with an oxic zone down to $15 \mathrm{~cm}$, reduction of Fe and Mn (oxyhydr) oxides between 15 and $27 \mathrm{~cm}$, and reduction of sulphate below $27 \mathrm{~cm}$. This scheme and the results on which it is based, which imply rapid consumption of electron acceptors, is consistent with the findings of Magariños-Álvarez et al. (2002), who interpreted highresolution seismic profiles as showing the presence of gas (possibly of biogenic origin) at a depth of $3 \mathrm{~m}$ near where M5GC was obtained.
Under steady-state conditions, with no changes in organic matter input or electron acceptors, the only diagenetic signals would be those indicating the current redox front ( $\mathrm{Fe}$ peaks at 9 and $27 \mathrm{~cm}$ ). However, changes in the quantity or reactivity of organic matter input and/or the degree of oxygenation of the sediment should leave signs in the sedimentary record (Wilson et al. 1985). In the Fe:Al and S:TOC profiles, there are peaks at 27,72 and $120 \mathrm{~cm}$ that are not attributable to detrital variations but to an increase in the precipitation of sulphides (mainly as pyrites according to the FESEM findings) that in turn must reflect an increase in the genesis of these minerals. The $27 \mathrm{~cm}$ level corresponds to the current sediment redox front, while the other 2 are interpreted as former suboxic-anoxic redox fronts that developed under more intense diagenetic conditions than prevailed for the rest of the core. Former oxic-suboxic redox fronts will not have been preserved because, as sediments accumulated, the upward advance of suboxic conditions will have caused the dissolution of iron oxide species.

The TOC:TN and $\delta^{13} \mathrm{C}$ profiles (Fig. 4) indicate that the sedimentary organic matter of the core is in general a mixture of material of marine origin, for which the TOC:TN ratio ranges from 4 to 7 and $\delta^{13} \mathrm{C}$ from -18 to $-20 \%$ (Meyers 1997, Lamb et al. 2006), and material of terrestrial origin (TOC:TN ratio $>17, \delta^{13} \mathrm{C}$ between -27 and $-30 \%$ ). Marine material apparently tends to predominate and, in particular, a rise in marine organic matter content is indicated by a lower TOC:TN ratio and less negative $\delta^{13} \mathrm{C}$ in 3 zones just above the $\mathrm{S}$ and Fe peaks at 27, 72 and $120 \mathrm{~cm}(6-24$, 54-66 and 111-117 cm). These zones also show a fall in TOC content with increasing depth (Fig. 4), and a rise in $R p$ that indicates greater reactivity. The latter finding is in keeping with the general rule that organic matter of marine origin is more labile than that of terrestrial origin (Wakeham \& Canuel 2005), and explains the fall in TOC content as due to increased degradation facilitated by the greater proportion of more labile, marine material (e.g. Canuel \& Martens 1996, Gong \& Hollander 1997, Damsté et al. 2002, Dai et al. 2009). The increase in labile organic matter also implies an increase in the consumption of electron acceptors (Peine \& Peiffer 1996, Blodau et al. 2000, Mladenov et al. 2010), and this explains the pyrite peaks at 27,72 and $120 \mathrm{~cm}$ as due to the reduction of $\mathrm{Fe}$ (oxyhydr)oxides and the precipitation of the released $\mathrm{Fe}^{2+}$ as pyrites.

There have thus been 3 periods of intensification of diagenetic processes due to an increase in the proportion of labile organic matter of marine origin that was being incorporated in the sediment. Given that the Ría de Muros is influenced by seasonal upwelling but also has significant fluvial and runoff input, the increase in the proportion of marine organic matter in its sedi- 
ments may be due either to an increased influx of upwelled water or to a decrease in the input of continental water.

\subsection{Palaeoclimatic interpretation of the results}

The sedimentation rates calculated for M5GC are within the normal range for the Galician Rías. That they are slightly lower than those of other cores obtained in the Ría de Muros (Lebreiro et al. 2006) may be due to M5GC having been extracted farther from the coast (Fig. 1). The calculated rates allow the dates of the 3 periods of more intense oceanic influence to be estimated as about 2900-2750, 1560-1250 and 560-140 cal. yr BP.

In the most recent of these periods, the increase in oceanic influence relative to continental input appears to have been due to both increased coastal upwelling and reduced continental runoff. An intensification of upwelling off the NW Iberian Peninsula, beginning around $500 \mathrm{cal}$. yr BP and continuing up to the present, has previously been inferred on the basis of studies of both the Rías Baixas (Diz et al. 2002, Lebreiro et al. 2006) and its adjacent shelf (González-Álvarez et al. 2005, Soares \& Dias 2006, Martins et al. 2006, 2007, Bernárdez et al. 2008b). However, the event period observed in M5GC, 560 to 140 cal. yr BP, coincides roughly with the Little Ice Age (LIA; Bradley \& Jones 1993), a period characterised by low temperatures and low rainfall. The decrease in recorded oceanic influence during the past $140 \mathrm{yr}$ may be due either to a decrease in upwelling or to an increase in rainfall, and consequent increase in terrestrial organic matter input, during the climatic warming that has occurred since AD 1850 (Desprat et al. 2003).

The lesser proportion of oceanic influence observed in M5GC between 1250 and 560 cal. yr BP coincides with the Medieval Warm Period (MWP), during which there was an increase in continental input to both the continental shelf (Mohamed et al. 2010) and the Rías of Vigo and Muros (Álvarez et al. 2005, Lebreiro et al. 2006). Álvarez et al. (2005), Lebreiro et al. (2006) and Mohamed et al. (2010) attribute the lesser proportion of oceanic influence to either the long-term predominance of negative NAO values, or to an increase in continental influence due to the increase in the population of northern Iberia that was associated with the reconquest of the peninsula from the Muslims.

Like the 560-140 cal. yr BP event, the second period of high relative oceanic influence observed in M5GC, between 1560 and $1250 \mathrm{cal}$. yr BP, appears to have a dual origin. On the one hand, it corresponds to the Dark Ages, a period that was relatively dry in comparison with the preceding Roman Warm Period (RWP) and the subsequent MWP; on the other hand, an intensification of upwelling on the NW Iberian continental shelf between 2200 and 1200 cal. yr BP has been inferred in several studies (Bartels-Jónsdóttir et al. 2006, Martins et al. 2006, 2007, Bernárdez et al. 2008b).

The period between the 1560-1250 and 2900-2750 cal. yr BP events coincides roughly with a period of positive NAO associated with a hot, humid climate both on the continental shelf (Bernárdez et al. 2008a) and in the Ría de Vigo (Diz et al. 2002, Álvarez et al. 2005). There is no published evidence of an intensification of upwelling off the NW Iberian Peninsula between 2900 and 2750 cal. yr BP, but the entry of oceanic water in the Ría de Muros may have been favoured around that time by the Mid-Holocene/Upper Holocene transition, a period of great climatic instability on the Galician coast (Diz et al. 2002, González-Álvarez et al. 2005). The larger grain size observed in the sediment of this age supports the notion that sedimentation took place under more energetic conditions during this period.

\section{CONCLUSIONS}

The sediments studied in the present work have high concentrations of organic matter from different sources but lack detrital variations indicative of climatic events. The results show the usefulness of relating multiple proxies to identify diagenetic signals in sediments of this kind, and the value of such signals for the reconstruction of palaeoclimate. Increases in the proportion of labile organic matter of marine origin in the sediment give rise to an intensification of diagenetic processes that is recorded as a decrease in TOC content followed by an increase in the concentration of authigenic pyrite. Since the relative increases in marine organic matter are due to climatic factors, their identification reveals climatic events. Three periods of intensification have been observed: 2900-2750, 1560-1250 and 560-140 cal. yr BP. All 3 were relatively cold, dry periods in the NW Iberian Peninsula.

Acknowledgements. This work is funded by projects 09MMA012312PR and 10MMA312022PR from the Xunta de Galicia, CTM2007-61227/MAR and IPT-310000-2010-17 from the MICINN (Ministerio de Ciencia e Innovación) of the Spanish Government and IGCP-526 from UNESCO. A.A. acknowledges funding from the FPU (Formación de Profesorado Universitario) programme of the Spanish Ministry of Education. P.A.-I. thanks the Xunta de Galicia (Spain) for its support through a postdoctoral contract and the Ángeles Alvariño programme for the short-stay fellowships. The authors thank A. M. Monge Soares from ITN (Portugal), and M. E. Fedi from LABEC (Italy) for performing the datings and allowing access to their installations. The authors also thank the 2 anonymous reviewers for their helpful comments. 


\section{LITERATURE CITED}

Álvarez MC, Flores JA, Sierro FJ, Diz P, Francés G, Pelejero C, Grimalt J (2005) Millennial surface water dynamics in the Ría de Vigo during the last 3000 years as revealed by coccoliths and molecular biomarkers. Palaeogeogr Palaeoclimatol Palaeoecol 218:1-13

Álvarez-Iglesias P, Rubio B (2008) The degree of trace metal pyritization in subtidal sediments of a mariculture area: application to the assessment of toxic risk. Mar Pollut Bull 56:973-983

Álvarez-Iglesias P, Rubio B (2009) Redox status and heavy metal risk in intertidal sediments in NW Spain as inferred from the degrees of pyritization of iron and trace elements. Mar Pollut Bull 58:542-551

Álvarez-Iglesias P, Quintana B, Rubio B, Pérez-Arlucea M (2007) Sedimentation rates and trace metal input history in intertidal sediments from San Simón Bay (Ría de Vigo, NW Spain) derived from ${ }^{210} \mathrm{~Pb}$ and ${ }^{137} \mathrm{Cs}$ chronology. J Environ Radioact 98:229-250

Álvarez-Salgado XA, Rosón G, Pérez FF, Pazos Y (1993) Hydrographic variability off the Rías Baixas (NW Spain) during the upwelling season. J Geophys Res 98:14447-14455

Banerjee SK, King J, Marvin J (1981) A rapid method for magnetic granulometry with applications to environmental studies. Geophys Res Lett 8:333-336

Bartels-Jónsdóttir HB, Knudsen KL, Abrantes F, Lebreiro S, Eiríksson J (2006) Climate variability during the last 2000 years in the Tagus Prodelta, western Iberian Margin: benthic foraminifera and stable isotopes. Mar Micropaleontol 59:83-103

Bernárdez P, González-Álvarez R, Francés G, Prego R, Bárcena MA, Romero OE (2008a) Late Holocene history of the rainfall in the NW Iberian peninsula - evidence from a marine record. J Mar Syst 72:366-382

Bernárdez P, González-Álvarez R, Francés G, Prego R, Bárcena MA, Romero OE (2008b) Palaeoproductivity changes and upwelling variability in the Galicia Mud Patch during the last 5000 years: geochemical and microfloral evidence. Holocene 18:1207-1218

Berner RA, Raiswell R (1983) Burial of organic carbon and pyrite sulfur in sediments over Phanerozoic time: a new theory. Geochim Cosmochim Acta 47:855-862

Björck S, Rittenour T, Rosén P, França Z and others (2006) A Holocene lacustrine record in the central North Atlantic: proxies for volcanic activity, short-term NAO mode variability, and long-term precipitation changes. Quat Sci Rev 25:9-32

Blodau C, Peine A, Hoffmann S, Peiffer S (2000) Organic matter diagenesis in acidic mine lakes. Acta Hydrochim Hydrobiol 28:123-135

Bond G, Showers W, Cheseby M, Lotti R and others (1997) A pervasive millenial-scale cycle in North Atlantic Holocene and glacial climates. Science 278:1257-1266

Bradley RS, Jones PD (1993) 'Little ice age' summer temperature variations: their nature and relevance to recent global warming trends. Holocene 3:367-376

Canfield DE, Thamdrup B, Hansen JW (1993) The anaerobic degradation of organic matter in Danish coastal sediments: iron reduction, manganese reduction and sulfate reduction. Geochim Cosmochim Acta 57:3867-3883

Canuel EA, Martens CS (1996) Reactivity of recently deposited organic matter: degradation of lipid compounds near the sediment-water interface. Geochim Cosmochim Acta 60:1793-1806

Cuesta A, Gallastegui G (2004) Galicia occidental. In: Vera JA (ed) Geología de España. Sociedad Geológica de España and Instituto Geológico y Minero de España (SGE-IGME),
Madrid, p 96-100

> Dai J, Sun MY, Culp RA, Noakes JE (2009) A laboratory study on biochemical degradation and microbial utilization of organic matter comprising a marine diatom, land grass, and salt marsh plant in estuarine ecosystems. Aquat Ecol 43:825-841

> Damsté JSS, Rijpstra WIC, Reichart GJ (2002) The influence of oxic degradation on the sedimentary biomarker record II. Evidence from Arabian Sea sediments. Geochim Cosmochim Acta 66:2737-2754

> Desprat S, Sánchez Goñi MF, Loutre M (2003) Revealing climatic variability of the last three millennia in northwestern Iberia using pollen influx data. Earth Planet Sci Lett 213:63-78

> Diz P, Francés G, Pelejero C, Grimalt JO, Vilas F (2002) The last 3000 years in the Ría de Vigo (NW Iberian Margin): climatic and hydrographic signals. Holocene 12:459-468

Emiroglu S, Rey D, Petersen N (2004) Magnetic properties of sediment in the Ría de Arousa (Spain): dissolution of iron oxides and formation of iron sulphides. Phys Chem Earth 29:947-959

Folk RL (1974) Petrology of sedimentary rocks. Hemphill Publishing, Austin, TX

Fraga F (1981) Upwelling off the Galician coast, Northwest Spain. In: Richards FA (ed) Coastal upwelling. American Geophysical Union, Washington, DC, p 176-182

Fraga F (1991) El afloramiento costero en la costa Atlántica de la Península Ibérica. Rev Acad Galega Cienc X:144-152

Froelich PN, Klinkhammer GP, Bender ML, Luedtke NA and others (1979) Early oxidation of organic matter in sediments of the eastern equatorial Atlantic: suboxic diagenesis. Geochim Cosmochim Acta 43:1075-1090

Gong C, Hollander DJ (1997) Differential contribution of bacteria to sedimentary organic matter in oxic and anoxic environments, Santa Monica Basin, California. Org Geochem 26:545-563

González-Álvarez R, Bernárdez P, Pena LD, Francés G, Prego R, Diz P, Vilas F (2005) Paleoclimatic evolution of the Galician continental shelf (NW of Spain) during the last 3000 years: from a storm regime to present conditions. J Mar Syst 54:245-260

Haese RR, Schramm J, Van Rutgers Der Loeff MM, Schulz HD (2000) A comparative study of iron and manganese diagenesis in continental slope and deep sea basin sediments off Uruguay. Int J Earth Sci 88:619-629

Hines ME, Bazylinski DA, Tugel JB, Lyons WB (1991) Anaerobic microbial biogeochemistry in sediments from two basins in the Gulf of Maine: evidence for iron and manganese reduction. Estuar Coast Shelf Sci 32:313-324

Hurrell J (1995) Decadal trends in the North Atlantic Oscillation: regional temperatures and precipitation. Science 269: 676-679

IGME (Instituto Geológico y Minero de España) (1978) Mapa geológico de España 1:50000, Noya. Servicio de publicaciones Ministerio de Industria y Energía, Madrid

Kristensen E (1990) Characterization of biogenic organic matter by stepwise thermogravimetry (STG). Biogeochemistry 9:135-159

Lamb AL, Wilson GP, Leng MJ (2006) A review of coastal palaeoclimate and relative sea-level reconstructions using $\delta^{13} \mathrm{C}$ and $\mathrm{C} / \mathrm{N}$ ratios in organic material. Earth Sci Rev 75: 29-57

> Lebreiro SM, Francés G, Abrantes FFG, Diz P and others (2006) Climate change and coastal hydrographic response along the Atlantic Iberian margin (Tagus Prodelta and Muros Ría) during the last two millennia. Holocene 16: 1003-1015

León I, Méndez G, Rubio B (2004) Geochemical phases of Fe 
and degree of pyritization in sediments from Ria de Pontevedra (NW Spain): implications of mussel raft culture. Cienc Mar 30:585-602

Loh PS, Miller AEJ, Reeves AD, Harvey SM, Overnell J (2008) Assessing the biodegradability of terrestrially-derived organic matter in Scottish sea loch sediments. Hydrol Earth Syst Sci 12:811-823

Magariños-Álvarez J, García-Gil S, Vilas F (2002) Shallow gas in sediments of the Ría de Muros-Noia (NW Spain): apparition forms and mapping. J Iberian Geol 28:107-122

Martins V, Jouanneau J, Weber O, Rocha F (2006) Tracing the late Holocene evolution of the NW Iberian upwelling system. Mar Micropaleontol 59:35-55

Martins V, Dubert J, Jouanneau J, Weber O and others (2007) A multiproxy approach of the Holocene evolution of shelfslope circulation on the NW Iberian continental shelf. Mar Geol 239:1-18

Mayewski PA, Rohling EE, Stager JC, Karlén W and others (2004) Holocene climate variability. Quat Res 62:243-255

> Meyers PA (1997) Organic geochemical proxies of paleoceanographic, paleolimnologic and paleoclimatic processes. Org Geochem 27:213-250

Mladenov N, Zheng Y, Miller MP, Nemergur DR and others (2010) Dissolved organic matter sources and consequences for iron and arsenic mobilization in Bangladesh aquifers. Environ Sci Technol 44:123-128

Mohamed KJ, Rey D, Rubio B, Vilas F, Frederichs T (2010) Interplay between detrital and diagenetic processes since the last glacial maximum on the northwest Iberian continental shelf. Quat Res 73:507-520

Mohamed KJ, Rey D, Rubio B, Dekkers MJ, Roberts AP, Vilas F (2011) Onshore-offshore gradient in reductive early diagenesis in coastal marine sediments of the Ria de Vigo, Northwest Iberian Peninsula. Cont Shelf Res 31:433-447

Mucci A, Richard LF, Lucotte M, Guignard C (2000) The differential geochemical behavior of arsenic and phosphorus in the water column and sediments of the Saguenay Fjord Estuary, Canada. Aquat Geochem 6:293-324

Peine A, Peiffer S (1996) Neutralisation processes in acid mine lake sediments. Adv Limnol 48:261-267

Pena LD, Francés G, Diz P, Nombela MA, Alejo I (2007) Climate fluctuations during the Holocene in NW Iberia: high and low latitude linkages. Clim Past Discuss 3:1283-1309

Pena LD, Francés G, Diz P, Esparza M, Grimalt JO, Nombela MA, Alejo I (2010) Climate fluctuations during the Holocene in NW Iberia: high and low latitude linkages. Cont Shelf Res 30:1487-1496

Pérez FF, Mouriño C, Fraga F, Ríos AF (1993) Displacement of water masses and remineralization rates off the Iberian Peninsula by nutrient anomalies. J Mar Res 51:869-892

Pérez-Arlucea M, Álvarez-Iglesias P, Rubio B (2007) Holocene evolution of estuarine and tidal-flat sediments in San Simón Bay, Galicia, NW Spain. J Coast Res 50:163-167

Reimer PJ, Baillie MGL, Bayliss A, Beck JW and others (2009) IntCal09 and Marine09 radiocarbon age calibration curves, 0 - 50,000 years cal BP. Radiocarbon 51:1111-1150

Rey D, Mohamed KJ, Bernabeu AM, Rubio B, Vilas F (2005) Early diagenesis of magnetic minerals in marine transi- tional environments: geochemical signatures of hydrodynamic forcing. Mar Geol 215:215-236

Rubio B, Pye K, Rae JE, Rey D (2001) Sedimentological characteristics, heavy metal distribution and magnetic properties in subtidal sediments, Ria de Pontevedra, NW Spain. Sedimentology 48:1277-1296

Rubio B, Álvarez-Iglesias P, Vilas F (2010) Diagenesis and anthropogenesis of metals in the recent Holocene sedimentary record of the Ría de Vigo (NW Spain). Mar Pollut Bull 60:1122-1129

Shaw TJ, Gieskes JM, Jahnke RA (1990) Early diagenesis in differing depositional environments: the response of transition-metals in pore water. Geochim Cosmochim Acta 54: 1233-1246

Snowball IF (1993) Geochemical control of magnetite dissolution in subarctic lake sediments and the implications for environmental magnetism. J Quat Sci 8:339-346

Soares AMM, Dias JMA (2006) Coastal upwelling and radiocarbon-evidence for temporal fluctuations in ocean reservoir effect off Portugal during the Holocene. Radiocarbon 48:45-60

Soares AMM, Dias JMA (2007) Reservoir effect of coastal waters off Western and Northwestern Galicia. Radiocarbon 49:925-936

Sørensen J, Jørgensen BB (1987) Early diagenesis from Danish coastal waters: microbial activity and Mn-Fe-S geochemistry. Geochim Cosmochim Acta 51:1583-1590

Stuiver M, Reimer PJ (1993) Extended ${ }^{14} \mathrm{C}$ data base and revised CALIB $3.0{ }^{14} \mathrm{C}$ age calibration program. Radiocarbon 35:215-230

Thompson J, Jarvis I, Green DRH, Green D (1998) Oxidation fronts in Madeira abyssal plain turbidites: persistence of early diagenetic trace-element enrichments during burial, Site 950. In: Weaver PPE, Schmincke HU, Firth JV, Duffield W (eds) Proc ODP; Sci Results 157:559-571

- Vilas F, Bernabeu AM, Méndez G (2005) Sediment distribution pattern in the Rias Baixas (NW Spain): main facies and hydrodynamic dependence. J Mar Syst 54:261-276

Vilas F, Bernabeu AM, Rubio B, Rey D (2010) Rías, estuarios y llanuras intermareales. In: Arche A (ed) Sedimentología. Del proceso físico a la cuenca sedimentaria. CSIC, Madrid, p 619-673

Wakeham SG, Canuel EA (2005) Degradation and preservation of organic matter in marine sediments. In: Volkman J (ed) The handbook of environmental chemistry, Vol 2. Series: reactions and processes: bio and chemical markers in environmental chemistry. Springer-Verlag, Berlin, p 295-321

Wehrli B, Stumm W (1989) Vanadyl in natural waters: adsorption and hydrolysis promote oxygenation. Geochim Cosmochim Acta 53:69-77

Wilson TRS, Thomson J, Colley S, Hydes DJ, Higgs NC, Sørensen J (1985) Early organic diagenesis: the significance of progressive subsurface oxidation fronts in pelagic sediments. Geochim Cosmochim Acta 49:811-822

Wooster WS, Bakun A, McClain DR (1976) The seasonal upwelling cycle along the eastern boundary of the north Atlantic. J Mar Res 34:131-141 